\title{
A MILP Model for Water Level Sensor Placement with Multi- Sensor and Multi-Disaster Areas
}

\author{
Prudensy F. Opit, Indah Y. Kairupan*, Fribianty M. Rasuh \\ Industrial Engineering Department, Faculty of Engineering, Universitas Katolik De La Salle Manado \\ Jl. Kairagi I Kombos Manado, Kairagi Satu, Manado, Indonesia \\ *Corresponding author: ikairupan@unikadelasalle.ac.id
}

\section{ARTICLE INFO}

Article history

Received May 27, 2021

Revised August 1, 2021

Accepted August 13, 2021

Available Online August 31, 2021

Keywords

Flood Prevention

Optimal Location

MILP Approach

Sensor Location

\begin{abstract}
A water level sensor is critical to measure water levels at strategic points in the river. The sensor location directly impacts the quality of the collected data sent to the flood early warning system. To prevent and minimize the risk of flooding, it is crucial to determine the optimal locations for water level sensor placement. This research proposes a Mixed-Integer Linear Programming (MILP) model for water level sensor placement considering multi-sensor and multi-disaster areas. In addition, this model was applied in a case study in Tikala River, Manado, Indonesia. The results indicated that all disaster areas could be covered by at least one single sensor. A sensitivity analysis was performed by running the model under several different budget scenarios. When the budget increases, the number of sensors and the coverage performance are getting larger. Thus, the proposed MILP model was able to determine the optimal locations for sensor placement under a limited budget.
\end{abstract}

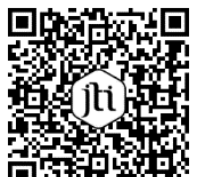

This is an open-access article under the CC-BY-SA license.

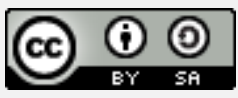

\section{Introduction}

A water level sensor is a part of an integrated Flood Early Warning System (FEWS) to support disaster prevention. Its function is to monitor the water level in the river and send the data to the system. Opit, et al. [1] implemented the water level sensor into the Early Warning System (EWS) technology to predict flooding events and broadcasts the information to the people living in the area at risk of floods. The development of water level sensor technology has grown rapidly. Its utilization supports the development of the FEWS. Several studies have applied the development of EWS based on mobile communication and information systems $[2,3]$. Other researchers used the internet as an integrated information source in disaster EWS with the Internet of Things (IoT's) technological model. This technology was integrated with embedded systems $[4,5]$. The concept of EWS is not only used in the field of disaster. However, it has been applied to various sectors to facilitate human activities [6, 7].

Appropriate sensor placement is a guarantee to obtain highly accurate information sent to the EWS [8]. The sensor location also plays a crucial role in monitoring water levels and enables fast flood detection. The sensor placement problem can be formulated with some optimization methods such as greedy algorithms, integer programming, progressive 
genetic algorithm, particle swarm algorithm [9], and an algorithm based on direct search [10]. A heuristic algorithm was also used to solve an Incremental Sensor Placement (ISP) problem [11]. In disaster management, Wu, et al. [12] proposed a sensor placement approach for post-earthquake monitoring in the water distribution network. The researchers proposed a complex three-way decision clustering method. The rainfall optimization algorithm modeled on raindrop flow over a mountainous surface was presented by Ferrolino, et al. [13]. However, none of the authors considered a MixedInteger Linear Programming (MILP) approach to solve the sensor location optimization problem.

Studies regarding water level sensor placement optimization for flood disaster prevention are minimal. A study conducted by Fattoruso, et al. [14] used a numerical model (enumerative search solution) to determine the optimal hydrometer sensors locations along the river in South Italy. Another study, although not specifically related to flood disaster prevention, discussed the optimal placement of pressure sensors for leak detection in water distribution systems [15]. Their research combined the pressured sensitivity matrix analysis and clustering techniques. Other studies related to sensor placement problems, in general, have been discussed by several researchers. Soman, et al. [16] developed a genetic algorithm-based optimization strategy and numerical approach for guided wave-based damage detection sensor placement. In a different case, Nasir and Syafiul [17] used numerical modeling simulation to place pressure sensors on winged ship models. An adaptation of the gradient descent algorithm was also used to optimize sensors' position and orientation [18]. Nishida, et al. [19]proposed two algorithms: greedy algorithm and convex relaxation method for sensor placement. The use of this method enabled them to set the candidate regions independently. A hybrid method based on QR factorization and dual-structure coding-based generalized genetic algorithm (GGA) was utilized to obtain the initial sensor placement and determine the locations of the sensor [20].

Although most studies above presented some optimization methods to solve the sensor placement problems, there are no studies that discuss the MILP approach to determine the optimal locations for water level sensor placement. MILP model is a powerful method that can be used for solving large and complex problems. This model is generally used to determine the optimal location based on the existing limitations [21]. Hence, we proposed a MILP model to maximize the number of water level sensors and determine their placement for effective coverage under budgetary constraints to minimize flood damage. Lasut, et al. [22] offered a MILP model that maximized the number of temporary emergency operations centers by considering multiple periods. Water level sensor placement should consider some critical factors such as the river channel capacity, population size, and probability of flooding in each disaster area. Wahjono and Setiaji [23] also stated that determining the location for sensor placement also depended on other vital factors. Some factors are such as signal availability (network performance), location reachability, and security level. Thus, all these factors would be considered in our model. The main contribution of this research is to support flood disaster prevention by determining the optimal locations for sensor placement using the MILP optimization model. For the case study, we applied our model to Tikala River in Manado city, Indonesia.

\section{Methods}

\subsection{Research stage}

The flow of this research is described as follows: preliminary observation, problem identification, and study objective specification. These steps included the interviews with 
the Public River Basin Management Organization officials, namely Balai Wilayah Sungai Sulawesi I (BWSS Sulawesi I) and North Sulawesi Disaster Management Board (BPBD Sulut). Next, we collected data such as the historical flood, heavy rainfall, river flow/channel capacity, cost, map locations (river location and flood candidate's location), total population, and signal availability. These data were obtained through direct observation on the fields, interviews with BWSS Sulawesi I and BPBD Sulut officials, and documentation analysis. Afterward, a new MILP model was formulated and ran by Lingo mathematical modeling software. Once the model was valid, we analyzed the results and provided a sensitivity analysis. Finally, the summary of the research and future study were discussed by the researchers.

\subsection{Case Study: Problem Description}

This research was a case study in Manado city, North Sulawesi, Indonesia. Flood is one of the most frequent disasters in Manado City [24]. One of the leading causes of flooding is high rainfall which causes the river to overflow and inundate the surrounding area. The flash flood disaster that hit North Sulawesi, including the city of Manado, on January 15, 2014, was one of the flood incidents that had a significant impact on both the community and the government. Based on the Indonesian National Board for Disaster Management (BNPB) data, more than 85,000 people were affected. In addition, 742 houses were washed away, and 3,688 houses were severely damaged, with a total material loss of up to IDR 1.87 trillion [24][25].

According to the North Sulawesi Disaster Management Board (BPBD Sulut), various efforts such as prevention, education, training, rehabilitation, and reconstruction have been carried out. However, these had not been able to fully overcome flooding incidents in Manado City. Flood Early Warning System (FEWS) is a system to predict flood events with enough confidence and lead time to take precautionary action [26]. However, despite the significance of these flood events, Manado city has yet implemented this flood warning system. It was partly due to the technical complexity of predicting flood events with accuracy and warning to take precautionary actions.

Most of the areas potentially affected by the flood are located in the riverside area $[27,28] .5$ major rivers cross the city of Manado: the Tondano river, the Tikala river, the Bailang river, the Sario river, and the Malalayang river; as well as two small rivers: the Maasing river and the Mahawu river [25, 29]. Compared to other rivers, during the periods of heavy rainfall, the Tikala river was rapidly overflowing, causing flooding in the area, especially in residential areas. Hence, this research focused on Tikala river, one of the rivers that caused the most significant impact during the flooding phenomenon on January 15, $2014[30,31]$.

\subsection{Model Assumptions}

In the proposed model, this research used assumptions: 1) a set of potential candidate locations for sensor placement in each disaster area was known, and 2) only one sensor could be placed (installed) in each selected candidate location.

\subsection{MILP: Model Formulation}

A MILP model was proposed in this research, letting $i=\{1,2,3 \ldots, \mathrm{I}\}$ be the set of disaster areas, and $j=\{1,2,3 \ldots, \mathrm{J}\}$ be the set of candidate locations for sensors placement. 
$J^{i}$ was the set of candidate locations for sensors placement in disaster area $i, i \in I$. The parameters and decision variables of this research are described in Table 1.

Table 1. Model Formulation

\begin{tabular}{|c|c|}
\hline \multicolumn{2}{|l|}{ Parameters: } \\
\hline$P_{i}$ & Probability of flooding in disaster area $i, i \in I$ \\
\hline$W_{i j}$ & $\begin{array}{l}\text { Criticality weight for river channel capacity at candidate location } j \text { in } \\
\text { disaster area } i, \sum_{j} W_{i j}=1 \text { and } W_{i j} \geq 0, i \in I, j \in J\end{array}$ \\
\hline$E_{i}$ & The total population in disaster area $i, i \in I$ \\
\hline$C_{j}$ & The production cost of a sensor to be positioned in location $j, j \in J$ \\
\hline$T C$ & Sensor production budget \\
\hline$S_{i j}$ & $\begin{array}{l}\text { Signal availability of candidate location } j \text { in disaster area } i, \sum_{j} S_{i j}= \\
1 \text { and } S_{i j} \geq 0, i \in I, j \in J\end{array}$ \\
\hline$F_{i j}$ & $\begin{array}{l}\text { The security level of candidate location } j \text { in disaster area } i \text {, } \\
\sum_{j} F_{i j}=1 \text { and } F_{i j} \geq 0, i \in I, j \in J\end{array}$ \\
\hline$N_{i j}$ & $\begin{array}{l}\text { Equal to } 1 \text { if the candidate location } j \text { in disaster area } i \text { is reachable for } \\
\text { sensor installation, otherwise } 0, i \in I, j \in J\end{array}$ \\
\hline
\end{tabular}

Decision variables:

$\begin{array}{ll}X_{i j} & \begin{array}{l}\text { Equal to } 1 \text { if the candidate location } j \text { in disaster area } i \text { is selected for the } \\ \text { sensor placement, otherwise } 0 .\end{array}\end{array}$

Objective function:

$$
\text { Maximize } \quad \sum_{i \in I} \sum_{j \in J} P_{i} X_{i j} E_{i} W_{i j} S_{i j} F_{i j}
$$

Constraints:

$$
\begin{array}{lc}
\sum_{j \in J^{i}} X_{i j} \geq 1 & \forall i \in I, \\
\sum_{j \in J} X_{i j} \leq N_{i j} & \forall i \in I, j \in J, \\
\sum_{i \in I} \sum_{j \in J} X_{i j} C_{j} \leq T C & \\
X_{i j}=[0,1] & \forall i \in I, j \in J .
\end{array}
$$

The objective function (1) maximized the population size that the water level sensor could cover. Constraint equation (2) ensured that at least one candidate location was selected in each disaster area. Constraint equation (3) assured that the sensor was placed in a reachable location. Constraint equation (4) imposed sensor production cost restriction. Finally, constraint equation (5) describes the binary constraint.

\subsection{Data Construction}

The disaster area in this model consisted of 8 sub-districts located on the banks of the Tikala River. There were two to three candidate positions for sensor placement in each disaster area. The river channel capacity of each existing candidate was calculated based 
on the river width, wet cross-sectional limit, and river flow velocity [30, 32]. Thus, the candidate position with the smaller river channel capacity should have been given a more significant weight value than the larger one.

Table 2 presents data estimation for the proposed MILP model. The cost required to manufacture sensors was 7,928,700 IDR/unit. Meanwhile, the available budget was estimated to be as big as $1 \%(80,000,000$ IDR) of the funds provided by BNPB. Since the sensor performance depends heavily on signal availability, we included the weight value of signal availability for each candidate location. For simplicity, we set all data for parameter $N_{i j}$ as 1 (all candidate locations were reachable for sensor installation).

The population number in disaster areas 1 to 8 were 3,$729 ; 2,718 ; 1,645 ; 3,185$; 2,$818 ; 6,726 ; 2,673 ; 4,226$; respectively. The probability of occurrence of flooding was assumed based on historical data of flood disasters that occurred in each disaster area in the last ten years (2010 to 2020). Therefore, the probability of flooding in disaster areas 1 to 8 were $0.10,0.17,0.13,0.13,0.17,0.10,0.10$, and 0.10 , respectively. Further data estimation such as river channel capacity, criticality weight for each channel, signal availability, and security level can be seen in Table 2.

Table 2. Data Estimation.

\begin{tabular}{|c|c|c|c|c|c|c|c|c|}
\hline $\begin{array}{l}\text { Dis. } \\
\text { Area }\end{array}$ & $\begin{array}{l}\text { Name of } \\
\text { Dis. Area }\end{array}$ & $\begin{array}{l}\text { Candi- } \\
\text { date }\end{array}$ & $\begin{array}{l}\text { South } \\
\text { Latitude }\end{array}$ & $\begin{array}{l}\text { East } \\
\text { Latitude }\end{array}$ & $\begin{array}{l}\text { River } \\
\text { Channel } \\
\text { Capacity } \\
(\mathrm{m} 3 / \mathrm{s})\end{array}$ & $\begin{array}{l}\text { Criticality } \\
\text { weight for } \\
\text { each } \\
\text { channel }\end{array}$ & $\begin{array}{l}\text { Signal } \\
\text { avail. }\end{array}$ & $\begin{array}{l}\text { Security } \\
\text { level }\end{array}$ \\
\hline \multirow{3}{*}{ I1 } & \multirow{3}{*}{$\begin{array}{l}\text { Dendengan } \\
\text { Dalam }\end{array}$} & J1 & 1.485472 & 124.852075 & 59.18 & 0.305 & 0.40 & 0.50 \\
\hline & & J2 & 1.478618 & 124.864737 & 58.21 & 0.393 & 0.30 & 0.30 \\
\hline & & J3 & 1.486012 & 124.851809 & 76.25 & 0.300 & 0.30 & 0.20 \\
\hline \multirow[b]{2}{*}{$\mathrm{I} 2$} & \multirow{2}{*}{ Banjer } & J1 & 1.481200 & 124.851594 & 47.52 & 0.552 & 0.50 & 0.50 \\
\hline & & J2 & 1.480976 & 124.852269 & 58.48 & 0.448 & 0.50 & 0.50 \\
\hline \multirow{3}{*}{ I3 } & \multirow{3}{*}{$\begin{array}{l}\text { Tikala } \\
\text { Ares }\end{array}$} & J1 & 1.482949 & 124.852236 & 80.89 & 0.285 & 0.35 & 0.40 \\
\hline & & J2 & 1.482332 & 124.851758 & 58.34 & 0.395 & 0.35 & 0.40 \\
\hline & & J3 & 1.480922 & 124.851852 & 65.33 & 0.319 & 0.30 & 0.20 \\
\hline \multirow[b]{2}{*}{$\mathrm{I} 4$} & \multirow{2}{*}{$\begin{array}{l}\text { Tikala } \\
\text { Baru }\end{array}$} & $\mathrm{J} 1$ & 1.480424 & 124.855973 & 72.62 & 0.508 & 0.45 & 0.50 \\
\hline & & $\mathrm{J} 2$ & 1.478671 & 124.860782 & 75.03 & 0.492 & 0.55 & 0.50 \\
\hline \multirow{3}{*}{ I5 } & \multirow{3}{*}{ Paal IV } & J1 & 1.471004 & 124.872038 & 63.65 & 0.287 & 0.40 & 0.40 \\
\hline & & $\mathrm{J} 2$ & 1.474636 & 124.869808 & 58.08 & 0.340 & 0.40 & 0.40 \\
\hline & & J3 & 1.477754 & 124.865444 & 48.97 & 0.373 & 0.20 & 0.20 \\
\hline \multirow[b]{2}{*}{ I6 } & \multirow{2}{*}{ Perkamil } & J1 & 1.472373 & 124.869810 & 57.33 & 0.654 & 0.55 & 0.60 \\
\hline & & J2 & 1.466918 & 124.874502 & 108.42 & 0.546 & 0.45 & 0.40 \\
\hline \multirow[b]{2}{*}{ I7 } & \multirow{2}{*}{ Ranomuut } & $\mathrm{J} 1$ & 1.476829 & 124.866836 & 60.47 & 0.507 & 0.50 & 0.50 \\
\hline & & $\mathrm{J} 2$ & 1.475548 & 124.867706 & 62.10 & 0.493 & 0.50 & 0.50 \\
\hline \multirow{3}{*}{ I8 } & \multirow{3}{*}{ Malendeng } & $\mathrm{J} 1$ & 1.463442 & 124.876885 & 65.02 & 0.338 & 0.40 & 0.35 \\
\hline & & J2 & 1.460831 & 124.879325 & 53.13 & 0.385 & 0.40 & 0.35 \\
\hline & & J3 & 1.465025 & 124.875861 & 74.04 & 0.276 & 0.20 & 0.30 \\
\hline
\end{tabular}

\section{Results and Discussion}

This research ran a mathematical model using Lingo 18.0 on an Intel ${ }^{\circledR}$ Core ${ }^{\mathrm{TM}}$ i7$7700 \mathrm{HQ}$ CPU 2.80GHz with 8GB RAM. Each computation time was less than 1 minute. 
The objective function value was 495.5979. Table 3 shows the optimum result of the selected candidate positions.

Table 3. Sensor Placement Results.

\begin{tabular}{lllll}
\hline $\begin{array}{l}\text { Disaster } \\
\text { area }\end{array}$ & $\begin{array}{l}\text { Candidate location } \\
(\mathrm{J} 1)\end{array}$ & $\begin{array}{l}\text { Candidate } \\
(\mathrm{J} 2)\end{array}$ & $\begin{array}{l}\text { location } \\
\text { Candidate location } 3\end{array}$ \\
\hline (I1) & $\sqrt{ }$ & - & - \\
\hline (I2) & $\sqrt{ }$ & - & - \\
\hline (I3) & - & $\sqrt{ }$ & \\
\hline (I4) & $\sqrt{ }$ & $\sqrt{ }$ & - \\
(I5) & - & $\sqrt{ }$ & \\
\hline (I6) & $\sqrt{ }$ & $\sqrt{ }$ & \\
\hline (I7) & $\sqrt{ }$ & - & - \\
\hline (I8) & - & $\sqrt{ }$ & \\
\hline
\end{tabular}

Based on the results obtained in Table 3, the total number of sensors to be placed was ten units. Each disaster area had at least one selected location, which meant that the sensors could cover all disaster areas; thus, this result was appropriate. This model considered crucial parameters such as rivel channel capacity, population size, probability of flooding, signal availability, security level, and location reachability. The selected location in each disaster area (refer to Table 2) had a relatively small river channel capacity, better signal availability, and a good security level. For example, in disaster area 1 (I1), candidate location 1 (J1), which had a smaller river channel capacity compared to candidate location 3 (J3), was selected. In this case, although candidate location 2 (J2) had the smallest rivel channel capacity, by considering other factors such as signal availability and security level, J1 remained selected.

While disaster areas $1,2,3,5,7$, and 8 only had one selected candidate location, disaster areas 4 and 6 had two selected candidate locations. It was mainly due to considering population size and the probability of flooding in each disaster area. Therefore, disaster areas 4 and 6 , which had a relatively large population and higher probability of flooding compared to other disaster areas, were prioritized for sensor placement. However, the results also indicated that the available budget highly restricted this model. Because of this budget limitation, some locations were not covered by the sensor. To show the importance of this available budget constraint, sensitivity analysis, as shown in Table 4 was provided.

Table 4. Scenario for Sensitivity Analysis

\begin{tabular}{ll}
\hline Scenario & Condition \\
\hline A & The available budget is increased by $20 \%$ \\
B & The available budget is increased by $50 \%$ \\
\hline C & The available budget is reduced by $20 \%$ \\
\hline
\end{tabular}


Scenario A and B (refer to Table 4) were performed by increasing the initial budget by $25 \%$ and $50 \%$. In comparison, scenario $\mathrm{C}$ was performed by decreasing as much as $20 \%$ of the initial budget. Table 5 displays the results of sensor placement based on scenarios $\mathrm{A}, \mathrm{B}$, and C. Scenario A was performed by increasing the available budget as much as $20 \%$ (from 80,000,000 to 96,000,000 IDR), the total number of sensors to be placed now increased to 12 units. 2 new locations were located in 2 disaster areas that the sensors had now covered: candidate location 2 (J2) in disaster area 2 (I2), and candidate location 2 (J2) in disaster area 7 (I7). Both locations were selected for their relatively smaller river channel capacity, better signal availability, good security level, and bigger population size than the other non-selected candidates. However, no candidate location 3 (J3) was selected for sensor placements, even though the available budget increased by $20 \%$.

Table 5. Sensor Placement Results of Scenarios A, B, and C

\begin{tabular}{|c|c|c|c|c|c|c|c|c|c|}
\hline \multirow{3}{*}{ Disaster area } & \multicolumn{3}{|c|}{ Scenario A } & \multicolumn{3}{|c|}{ Scenario B } & \multicolumn{3}{|c|}{ Scenario C } \\
\hline & \multicolumn{3}{|c|}{ Candidate location } & \multicolumn{3}{|c|}{ Candidate location } & \multicolumn{3}{|c|}{ Candidate location } \\
\hline & $(\mathrm{J} 1)$ & $(\mathrm{J} 2)$ & (J3) & $(\mathrm{J} 1)$ & (J2) & (J3) & (J1) & (J2) & (J3) \\
\hline (I1) & $\sqrt{ }$ & - & - & $\sqrt{ }$ & $\sqrt{ }$ & - & $\sqrt{ }$ & - & - \\
\hline (I2) & $\sqrt{ }$ & $\sqrt{ }$ & & $\sqrt{ }$ & $\sqrt{ }$ & & $\sqrt{ }$ & - & \\
\hline (I3) & - & $\sqrt{ }$ & - & - & $\sqrt{ }$ & - & - & $\sqrt{ }$ & - \\
\hline (I4) & $\sqrt{ }$ & $\sqrt{ }$ & & $\sqrt{ }$ & $\sqrt{ }$ & & $\sqrt{ }$ & - & \\
\hline (I5) & - & $\sqrt{ }$ & - & $\sqrt{ }$ & $\sqrt{ }$ & - & - & $\sqrt{ }$ & - \\
\hline (I6) & $\sqrt{ }$ & $\sqrt{ }$ & & $\sqrt{ }$ & $\sqrt{ }$ & & $\sqrt{ }$ & - & \\
\hline (I7) & $\sqrt{ }$ & $\sqrt{ }$ & & $\sqrt{ }$ & $\sqrt{ }$ & & $\sqrt{ }$ & - & \\
\hline (I8) & - & $\sqrt{ }$ & - & $\sqrt{ }$ & $\sqrt{ }$ & - & - & $\sqrt{ }$ & - \\
\hline
\end{tabular}

Table 5 also describes the result of scenario B. This scenario was performed by increasing the available budget by $50 \%$ (from 80,000,000 to 120,000,000 IDR). As a result, the total number of sensors The new selected locations were candidate location 2 (J2) in disaster area 1 (I1), candidate location 1 (J1) in disaster area 5 (I5), and candidate location 1 (J1) in disaster area 8 (I8). Nonetheless still, not a single candidate location 3 (J3) had been selected. Due to their relatively bigger river channel capacity, lower signal availability, and lower security level than the other selected candidates.

Meanwhile, scenario C reduced the available budget to $20 \%$ (from 80,000,000 to $64,000,000$ IDR). The result was obvious. The total number of sensors to be placed was reduced to only eight units, with one selected candidate location for each disaster area. It meant all disaster areas could still be covered, ensuring that this result was still acceptable. However, the coverage performance was less than 50\%. Hence, the model is valid. However, as we tried to reduce the budget by $30 \%$, the solver determined no feasible solution. It suggested that the budget available should not be reduced by more than $20 \%$. It already reached the lowest budget limitation to run the model successfully. 
Table 6. Results Comparison

\begin{tabular}{cccc}
\hline & $\begin{array}{c}\text { Number of sensors } \\
\text { (unit) }\end{array}$ & $\begin{array}{c}\text { Available budget } \\
{[26]}\end{array}$ & $\begin{array}{c}\text { Coverage } \\
\text { performance (\%) }\end{array}$ \\
\hline Original Result & 10 & $80,000,000$ & $50 \%$ \\
\hline Scenario A & 12 & $96,000,000$ & $60 \%$ \\
\hline Scenario B & 15 & $120,000,000$ & $75 \%$ \\
\hline Scenario C & 8 & $64,000,000$ & $40 \%$ \\
\hline
\end{tabular}

Table 6 depicts the result comparison between the original result, scenario A, scenario $\mathrm{B}$, and scenario $\mathrm{C}$. The results indicated that as the budget increased, the number of sensors gradually increased. In addition, the coverage performance or the number of locations covered by the sensors was also getting larger. Therefore, it is clear that budget availability becomes the most restricted parameter in this model.

Finally, the results also claimed that this MILP model could effectively determine optimal locations for the water level sensor. Our model might be easier to manipulate or adjust than previous research on sensor placement optimization for disaster prevention $[12,13]$. Our model also tried to include more aspects of the real world, such as signal availability, security level, and location reachability of each candidate location. Lastly, to prevent flood damage, we recommend that the central or local government increase the budget. Therefore, we would place more sensors and cover more locations to prevent more losses due to unprecedented floods by increasing the budget.

\section{Conclusion}

In this research, a MILP model to determine the optimal water level sensor placement locations was introduced. In this MILP model, essential parameters such as rivel channel capacity, population size, probability of flooding, signal availability, location reachability, and security level in each disaster area were highly considered. The results stated that each disaster area was covered by at least one single sensor, which proved that the model was working properly. In this case, the optimum number of sensors to be placed in 20 different potential locations was restricted to 10 units, giving up to $50 \%$ coverage performance. A sensitivity analysis was then performed to show the importance of budget available constraints. As shown in scenarios for sensitivity analysis, the number of sensors to be placed and the coverage performance were getting more significant when the budget increased. Therefore, we concluded that budget availability became the most restricted constraint in this model. Therefore, by adding more budget, more locations could be covered by the sensors.

Future work can focus on the mathematical model by adding new parameters such as river slope and riverbank soil structure to get a more detailed analysis. In addition, the research can also be extended by applying this sensor placement model to various other rivers in the same and different cities.

\section{Data Availability}

All data generated or analyzed during this study are included in this article. 


\section{Declarations}

Author contributions: The conceptualization, mathematical model formulation, analysis, writing, review, and editing were carried out by P.F. Opit. The methodology, writing, and editing were carried out by I.Y. Kairupan. F.M. Rasuh carried out the data construction and mathematical model testing.

Funding statement: This research was funded by the Industrial Engineering Department, Faculty of Engineering, Universitas Katolik De La Salle Manado.

Conflicts of Interest: The authors declare that no conflict of interests occurred.

Additional information: No additional information is available for this paper.

\section{Acknowledgment}

The authors would like to thank the anonymous reviewers for their helpful suggestions to improve this paper.

\section{References}

[1] I. Kairupan, K. Dame, and I. Masala, " Mechanical Design for Flooding Detection System Using Motor Direct Current Control Based On Arduino," Global Scientific Journal, vol. 7, no. 9, 2019.

[2] I. F. Astuti, A. N. Manoppo, and Z. J. S. Arifin, "Sistem peringatan dini bahaya banjir kota Samarinda mengunakan sensor ultrasonic berbasis mikrokontroler dengan buzzer dan SMS," vol. 22, no. 1, pp. 30-34, 2018. https://jurnal.wicida.ac.id/index.php/sebatik/article/view/209.

[3] M. Ayaz, M. Ammad-Uddin, and I. J. I. S. J. Baig, "Wireless sensor's civil applications, prototypes, and future integration possibilities: A review," vol. 18, no. 1, pp. 4-30, 2017. http://doi.org/10.1109/JSEN.2017.2766364.

[4] D. Satria, S. Yana, R. Munadi, and S. Syahreza, "Flood Early Warning Information System For Multilocation Based Android," International Journal of Engineering Technologies Management Research, vol. 5, no. 8, pp. 47-53, 2018. https://doi.org/10.29121/ijetmr.v5.i8.2018.279.

[5] I. Kairupan, Z.-Y. Huang, H.-C. Chang, and C.-W. Chang, "Emergency navigation and alarm with flooding models-A real case study of Manado City," in 2016 International Conference On Communication Problem-Solving (ICCP), 2016, pp. 12: IEEE. http://doi.org/10.1109/ICCPS.2016.7751120.

[6] L. Sitanayah, A. Angdresey, and E. Kristalino, "A sensor-based application for road conditions detection: poster abstract," presented at the Proceedings of the 18th Conference on Embedded Networked Sensor Systems, Virtual Event, Japan, 2020. http://doi.org/10.1145/3384419.3430437.

[7] Y.-C. Tseng, M.-S. Pan, and Y.-Y. Tsai, "Wireless sensor networks for emergency navigation," Computers \& Chemical Engineering, vol. 39, no. 7, pp. 55-62, 2006. http://doi.org/10.1109/MC.2006.248.

[8] Q. Shi, X. Wang, W. Chen, and K. Hu, "Optimal sensor placement method considering the importance of structural performance degradation for the allowable loadings for damage identification," Applied Mathematical Modelling, vol. 86, pp. 384-403, 2020. https://doi.org/10.1016/j.apm.2020.05.021.

[9] M. Rebolledo, S. Chandrasekaran, and T. Bartz-Beielstein, "Sensor Placement for Contamination Detection in Water Distribution Systems,", 2020. 
[10] S. Bianco and F. Tisato, "Sensor placement optimization in buildings," in Image Processing: Machine Vision Applications V, 2012, vol. 8300, p. 830003: International Society for Optics and Photonics. https://doi.org/10.1117/12.911021.

[11] X. Xu, Y. Lu, S. Huang, Y. Xiao, and W. Wang, "Incremental sensor placement optimization on water network," in Joint European Conference on Machine Learning and Knowledge Discovery in Databases, 2013, pp. 467-482: Springer. https://link.springer.com/chapter/10.1007/978-3-642-40994-3_30.

[12] J. Wu, D. Ma, W. Wang, and Z. Han, "Research on sensor placement for disaster prevention in water distribution networks for important users," Sustainability, vol. 12, no. 2, p. 723, 2020 2020. https://doi.org/10.3390/su12020723.

[13] A. R. Ferrolino, J. E. C. Lope, and R. G. Mendoza, "Optimal location of sensors for early detection of tsunami waves," in International Conference on Computational Science, 2020, pp. 562-575: Springer. https://doi.org/10.1007/978-3-030-50417$5 \_42$.

[14] G. Fattoruso et al., "Optimal sensors placement for flood forecasting modelling," Procedia Engineering, vol. 119, pp. 927-936, 2015. https://doi.org/10.1016/j.proeng.2015.08.971.

[15] A. Puri, K. Valavanis, and M. Kontitsis, "Statistical profile generation for traffic monitoring using real-time UAV based video data," in 2007 Mediterranean Conference on Control \& Automation, 2007, pp. 1-6: IEEE. http://doi.org/10.1109/MED.2007.4433658.

[16] R. Soman, P. Kudela, K. Balasubramaniam, S. K. Singh, and P. Malinowski, "A study of sensor placement optimization problem for guided wave-based damage detection," Sensors, vol. 19, no. 8, p. 1856, 2019. https://doi.org/10.3390/s19081856.

[17] M. Nasir and A. Syafiul, "Optimalisasi Penempatan Sensor Untuk Pengukuran Distribusi Tekanan Model Kapal Bersayap," Wave: Jurnal Ilmiah Teknologi Maritim, vol. 5, no. 1, pp. 2011. https://doi.org/10.29122/jurnalwave.v5i1.3358.

[18] V. Akbarzadeh, J.-C. Lévesque, C. Gagné, and M. Parizeau, "Efficient sensor placement optimization using gradient descent and probabilistic coverage," Sensors, vol. 14, no. 8, pp. 15525-15552, 2014. https://doi.org/10.3390/s140815525.

[19] T. Nishida, N. Ueno, S. Koyama, and H. Saruwatari, "Sensor placement in arbitrarily restricted region for field estimation based on Gaussian process," in 2020 28th European Signal Processing Conference (EUSIPCO), 2021, pp. 22892293: IEEE. http://doi.org/10.23919/Eusipco47968.2020.9287222.

[20] T. H. Yi, H. N. Li, and M. Gu, "Optimal sensor placement for structural health monitoring based on multiple optimization strategies," The Structural Design of Tall Special Buildings, vol. 20, no. 7, pp. 881-900, 2011. https://doi.org/10.1002/tal.712.

[21] C. Livia, "Usulan Penjadwalan Produksi untuk Meminimalkan Total Tardiness dengan Metode Integer Linear Programming Pada Bagian Produksi Printing PT Mitra Mulia Makmur," Jurnal Teknik Industri, vol. 18, p. 127, 2017. http://doi.org/10.22219/JTIUMM.Vol18.No2.127-137.

[22] A. C. Lasut, P. F. Opit, and R. Rottie, "The MILP Model for Locating the Temporary Disaster Emergency Operation Centers in Manado Indonesia," Jurnal Teknik $\begin{array}{llllll}\text { Industri, } & \text { vol. } 21, \quad \text { no. } 1, \quad \text { pp. } & 46-57,\end{array}$ https://doi.org/10.22219/JTIUMM.Vol21.No1.46-57.

[23] H. D. Wahjono and G. Setiaji, "Instalasi Sistem Pemantauan Kualitas Air Online Berbasis GSM di Sungai Ciliwung Segmen Istiqlal," Jurnal Air Indonesia, vol. 8, no. 1, 2018. http://dx.doi.org/10.29122/jai.v8i1.2384. 
[24] R. Riyandari, "“Water Front City" Mitigasi Bencana Banjir Di Kelurahan Dendengan Luar, Kota Manado," Jurnal Sains dan Teknologi Mitigasi Bencana, vol. 13, no. 1, pp. 57-64, 2018. https://doi.org/10.29122/jstmb.v13i1.3361.

[25] B. Laurensz, F. Lawalata, and S. Y. J. Prasetyo, "Potensi Resiko Banjir dengan Menggunakan Citra Satelit (Studi Kasus: Kota Manado, Provinsi Sulawesi Utara)," Indonesian Journal of Computing Modeling, vol. 2, no. 1, pp. 17-24, 2019. https://ejournal.uksw.edu/icm/article/view/2536.

[26] C. Hill, F. Verjee, and C. Barrett, "Flash flood early warning system reference guide," University Corporation for Atmospheric Research: Boulder, CO, USA, p. 204, 20102010.

[27] G. B. Sahetapy and H. Poli, "Analisis Jalur Evakuasi Bencana Banjir Di Kota Manado," SPASIAL, vol. 3, no. 2, pp. 70-79, 2016. https://ejournal.unsrat.ac.id/index.php/spasial/article/view/12536.

[28] Y. Sudamara, B. F. Sompie, and R. J. Mandagi, "Optimasi penanggulangan bencana banjir Di kota manado dengan metode AHP (analytical hierarchy process)," Jurnal Ilmiah Media Engineering, vol. 2, no. 4, 2012.

[29] F. S. Gay, F. Warouw, and E. D. Takumansang, "Perencanaan Kawasan Sempadan Sungai Sawangan di Kota Manado," SPASIAL, vol. 5, no. 1, pp. 105-117, 2018. https://ejournal.unsrat.ac.id/index.php/spasial/article/view/19284.

[30] H. A. Telah, J. A. Rombang, and H. D. Walangitan, "Modeling Tutupan Lahan di DAS Tikala Berdasarkan Kapasitas Saluran Sungai Tikala," EUGENIA, vol. 24, no. 2, 2018. https://doi.org/10.35791/eug.24.2.2018.22805.

[31] D. Makasaehe, L. A. Hendratta, and J. S. Sumarauw, "Kajian Pemetaan Banjir Dengan Hec-Georas Studi Kasus: Sungai Tondano," JURNAL SIPIL STATIK, vol. 8, no. 3, 2020. https://ejournal.unsrat.ac.id/index.php/jss/article/view/28750.

[32] N. Yuniarti, D. Hariyanto, S. Yatmono, and M. Abdillah, "Design and Development of IoT Based Water Flow Monitoring for Pico Hydro Power Plant," nt. J. Interact. Mob. Technol., vol. 15, no. 7, pp. 69-80, 2021. https://doi.org/10.3991/ijim.v15i07.18425. 